\title{
Towards an emotional electoral geography: The performativity of emotions in electoral campaigning in Ecuador
}

\author{
Carolin Schurr \\ University of Bern, Department of Geography E' Interdisciplinary Center for Gender Studies, Hallerstr. 12, 3012 Bern, Switzerland
}

\section{A R T I C L E I N F O}

\section{Article history}

Received 3 July 2012

Received in revised form 29 April 2013

\section{Keywords:}

Electoral geography

Populism

Emotions

Performativity

Visual ethnography

Ecuador

\begin{abstract}
A B S T R A C T
Building on feminist geopolitics and emotional geography, this paper calls for an emotional electoral geography that understands electoral practices as grounded, embodied and intertwined with the timespatial context in which electioneering takes 'place'. I argue that a performative understanding of emotions not only facilitates linking emotions to certain places, histories and (collective) bodies, but also helps to think of emotions as expressed both through body and speech acts. Empirically, the paper draws on visual ethnographic fieldwork of a local electoral campaign in an Amazon town in Ecuador. The observed emotional performances of female and indigenous local politicians are compared with the emotional performances of national populists who are mainly mestizo men and have dominated Ecuadorian politics throughout the past decades. The research identifies similar emotional patterns turning around a Manichean rhetoric of rabia (rage) and amor (love). The comparison shows, however, that the emotional performances of different candidates performatively generate the gendered, racialized and classed boundaries of el pueblo in different ways in particular times and places. The empirical case study illustrates the claim that electoral geographies need to be more attentive to the emotional dimension of electoral spaces to understand the affective dimension of contemporary populist politics.
\end{abstract}

(c) 2013 Elsevier Ltd. All rights reserved.

\section{Bringing emotions into electoral geography}

'Que se vayan, que se vayan todos'

[throw them all out]' (protest chant, protest against the government of president Lucio Gutiérrez in Quito, 13 April 2005).

Participating with my fellow students in the protests against the Ecuadorian President Lucio Gutiérrez (President between 2003-2005) in April 2005, chanting 'que se vayan todos' and raising my hand rhythmically with the other protesters, it was the first time that I experienced the emotions ${ }^{2}$ of Ecuadorian politics with

E-mail address: schurr@giub.unibe.ch

1 To problematize the political act of speaking for/with others (e.g. Alcoff, 1991), I make my agency as a translating geographer visible by using a 'translation which keeps words in the source language as a visual marker of indeterminacy' (Müller, 2007: 212).

2 While recent discussions in human geography differentiate between affect and emotion (see Pile, 2010; Thien, 2005), I follow Ahmed's (2004b: 39) argument here that 'even seeming direct responses actually evoke past histories, and that this process bypasses consciousness, through bodily memories. So sensations may not be about conscious recognition, but this does not mean they are "direct" in the sense of immediate. Further, emotions clearly involve sensations: this analytic distinction between affect and emotion risks cutting emotions off from the lived experiences of being and having a body'. my own body. While I was moved by the emotions present in these protests, which resulted in the overthrow of the populist President Lucio Gutiérrez, it was not until conducting fieldwork in the 2009 electoral campaign that I started to think more systematically about the role of emotions in the constitution of political spaces. Accompanying female, indigenous and Afro-Ecuadorian candidates in their local campaign, I was interested in the extent to which the emotional campaign performances of these new political subjects ${ }^{3}$ reproduce or challenge populist campaign practices.

Populism has dominated the political scenario in Ecuador in its different guises as classic populism (1940s-1970s), neoliberal populism (1990s) and radical left-wing populism (since 2007) during the last decades (de la Torre, 2010a). Between 1997 and 2005, however, several populist presidents were forced to leave office before completing their terms through popular protests (de la Torre and

\footnotetext{
${ }^{3}$ I differentiate here between new and populist political subjects. The term 'new political subjects' refers to women, indigenous and Afro-Ecuadorian people who have been excluded from formal citizenship since colonial times. While these social groups have a long history of political struggle in Ecuador, they have appeared in institutionalized politics only recently in more significant numbers. The term new political subjects results from their participation in 'new social movements' through which they have fought for their political rights. Populist politicians are considered those politicians who have dominated the political scene during the past decades. The distinction between new and populist political subjects is made by the different political subjects themselves and is taken up here for analytical purposes.
} 
Conaghan, 2009). During this decade of political instability, new political subjects emerged that had gained access to electoral politics as a consequence of social movement protests during the 1980s and 1990s (see Radcliffe, 2008; Van Cott, 2008; Walsh and García, 2002). The (post-)colonial patriarchal, mono-ethnic and especially populist political system was a central target of protests by ethnic and women's movements. One outcome of these protests is the indigenous party Pachakutik, which was founded in 1996 (Sánchez-Parga, 2007). Another is the successful implementation of a gender quota law in 1997 (Cañete, 2004; Vega Ugalde, 2005). Emerging at a time of political crisis, these new political subjects distanced themselves clearly from former - mainly male and mestizo (a 'mixed' person from indigenous and European antecedents) - populist politicians, while emphasizing that they were the true representatives of el pueblo. The following empirical analysis asks to what extent the new political subjects reproduce the emotional patterns of populist campaigns. Focusing on the production of affective political communities, the paper investigates how the emotional performances of populist and new political subjects include or exclude certain bodies in their political community. How are political antagonisms constructed through the emotional campaign performances of these two groups of political subjects that align certain emotions with differently racialized, gendered and classed bodies?

The paper argues that electoral geographies have to take emotions seriously in order to understand electoral dynamics in general and the dominance of populist campaigns in Latin America in particular. So far, however, emotional geographies have been oriented 'more towards social, cultural and environmental dimensions, than mapping out the political geographies of emotion' (Pain et al., 2010: 973). The different subfields of political geography have engaged to different extents with issues of emotion. Recently, feminist geopolitics has made important inroads in studying the emotional dimension of geopolitical events and processes (Fluri, 2011; Koopman, 2011; Pain, 2009, 2010; Sharp, 2011; Smith, 2011). While feminist political geographers have long questioned prevalent dichotomies about formal/informal politics, public/private spaces and the characterization of these spaces as rational/emotional and masculine/ feminine (Blunt and Rose, 1994; Staeheli, 1996; Staeheli et al., 2004; Staeheli and Mitchell, 2004), they have not yet paid attention to the emotional dimension of institutionalized politics. One reason for this can be found in feminist political geographers' endeavor to open up the narrow, masculinist, and state-centered perspective of mainstream political geography (see e.g. Dowler and Sharp, 2001; Hyndman, 2004; Staeheli et al., 2004). In their attempt to refocus attention on diverse political settings beyond the state, such as social movement politics (Conway, 2008; Gruszczynska, 2009) or politics of care (England, 2003; Pratt, 2004), institutionalized politics and related issues such as elections and campaigning have remained on the margins of feminist political geography.

At the same time, in electoral geography 'atheoretical, quantitative and positivist approaches' (Cupples, 2009: 111) dominate and have increasingly become the subject of critique (Agnew, 1990; Johnston and Pattie, 2004; Warf and Leib, 2011). While there have been important contributions to electoral geography from a feminist perspective (e.g. Nelson, 2006; Secor, 2004; Staeheli, 2004), the role of emotions in the constitution of electoral spaces has not been taken into account in this field. Following a feminist political agenda that calls for the need to embody, locate and ground political action (Dowler and Sharp, 2001; Hyndman, 2001, 2004), this paper aims to develop an emotional electoral geography that asks how emotions are expressed and evoked in electoral campaigns. It thus calls for refocusing attention on institutionalized politics as one of many sites of political struggles where political communities are generated through emotional performances.

Finally, my endeavor to develop what I call an emotional electoral geography also builds on work in political science which has shown that 'emotions play an explicit and central role in bonding citizens, party, party platform, and elected officials' (Marcus, 2002: 37). In his attempt to explain the Bush administration's coalition, political scientist Connolly (2005: 870) argues that 'in politics [...] loosely associated elements [such as affect, spirituality, and economic interests] fold, bend, blend, emulsify, and dissolve into each other, forging a qualitative assemblage resistant to classical models of explanation'. Taking Connolly's argument as a starting point, this paper engages with the emotional and spiritual dimensions of electoral campaigning. While political scientists have explored the emotional dimensions of campaign advertising (Ansolabehere and Iyengar, 1995), campaign speeches (Hampton, 2009), campaign events (Van Zoonen, 2005), and canvassing (Goldstein and Holleque, 2010), their experimental or neuropsychological studies have been mainly concerned with the impact of candidates' emotional performances on electoral results (see e.g. Marcus et al., 2000, 2006; Marcus and Mackuen, 1993). This paper contributes to this body of literature by developing a methodological framework that combines (visual) ethnography with qualitative interviews to capture the emotional dimension of electoral spaces. Focusing on the way emotional campaign practices performatively generate political communities, the paper opens the black boxes still present in electoral studies that often treat political subjectivities and collectivities as pregiven entities.

\section{The performativity of emotions in political speech}

Electoral campaigns are grounded in antagonistic relations between different political candidates who claim to represent certain political communities. Emotions play a crucial role in building a relationship between a collective of constitutents and electoral candidates as well as in generating a sense of community among supporters. Work in political geography and geopolitics has highlighted that the formation of political identities is based on often highly emotional Othering that create antagonistic relations between an 'us' and 'them' (Laketa, 2013; Müller, 2009; Reuber and Wolkersdorfer, 2002; Smith, 2012). Ahmed (2004b: 10) states that 'emotions create the very effect of the surfaces and boundaries that allow us to distinguish an inside and an outside in the first place. So emotions are not simply something 'I' or 'we' have. Rather, it is through emotions, or how we respond to objects and others, that surfaces or boundaries are made: the 'I' and the 'we' are shaped by, and even take the shape of, contact with others'. In this vein, she turns emotions from being side effects of identity formation processes into the central element that produce political identities. Ahmed's notion of the performativity of emotion contributes to further conceptualizing these emotionalized Otheirng processes in political spaces. It helps to analyze how 'emotions work to secure [political] collectives' and how political antagonisms are constructed by aligning 'some subjects with some others and against some others' (Ahmed, 2004a: 25). Ahmed draws on Judith Butler's notion of performativity to make her claim that 'emotions do things, and work to align individuals with collectives' (Ahmed, 2004a: 26). For Butler (1993: xxviii), performativity is about the 'power of discourse to produce effects through reiteration'. Hence, "[p]erformativity is not a singular "act", for it is always a reiteration of a norm' (Butler, 1993: xxi). Butler (2010: 147) further points out that for a performative speech act to be felicitous in the sense that it brings about action, certain conditions need to be in place. A performative speech act can only 'succeed' if it repeats a coded or iterable utterance (Butler, 2010).

Butler's (2004: 198) argument that subjects (and collectives) are performatively constituted through iterative speech and body acts is crucial to understanding Ahmed's (2004b: 92) discussion about the stickiness of emotions. For Ahmed, it is the repetition 
of signs - the stickiness of the sign to an object - that allows others to be attributed with emotional value. To understand emotions as performative means then that emotions 'both repeat past associations as well as generate their object' (Ahmed, 2004a: 32). In the same way as Austin (1962: 14-15) shows that speech acts are only felicitous if a conventional procedure (such as a campaign script) exists that guides the action, performative emotions rely on previous norms and conventions of speech and body acts to generate the object that they name (for example the menacing (post-)colonial white elite). For a speech or body act to become performative, it needs to be spoken or enacted to others, 'whose shared witnessing [of the menacing white men] is required for the affect to have an effect' (Ahmed, 2004b: 94). An audience is required for a speech or body act to be felicitous, as the audience needs to repeat the attribution of a certain feeling to an object articulated in the speech act. The speech act not only generates the object (the menacing white men) but also a community of those who are bound together through shared feelings (e.g. of fear).

In short, Ahmed's performative notion of emotion shows how emotions align with (collective) bodies (for example the indignation of indigenous bodies about their discrimination in post-colonial societies), how these emotions come to stick to certain bodies (for example the indignant indigenous body and the menacing white body) and places (for example the urban centers where (post-)colonial power is located) through the iterative citation of (geo-)political ${ }^{4}$ storylines (for example post-colonial exploitation). It provides a way of thinking about how these associations move subjects in space in specific ways (for example indigenous people avoiding contact with racist white bodies by staying away from urban centers) and bound them together in a community of witnesses.

These examples highlight three important aspects of Ahmed's approach for the following analysis. First, how certain bodies feel about a group of other bodies is not simply a matter of individual impressions that are created anew in the present, but 'the contact is shaped by past histories of contact' (Ahmed, 2004b: 7). The performativity of emotions consists in generating a collective through the iterative attachment of certain emotions to certain bodies. Second, emotions are not only performatively aligned to (collective) bodies but also to places and spaces. Hence, emotions play a crucial role in the iterative performances that bring places and spaces into being (Gregson and Rose, 2000; Schurr, in press). Third, Ahmed emphasizes that while subjects may stick certain emotions consciously to specific bodies and places (e.g. as part of a campaign strategy), their negotiations and performances are always mediated by the unconscious, such as bodily memories, past associations and normative imaginaries that shape their emotions. In so doing, Ahmed's approach helps to create a counterweight to the dominant view in electoral studies that considers the emotional performances of candidates as strategic performances of consciously acting subjects (e.g. Ansolabehere and Iyengar, 1995; Marcus and Mackuen, 1993).

While this paper aims to provide a counterweight to the assumption of a Cartesian subject that dominates electoral studies, conceptualizing the emotional performances of electoral candidates as both conscious and unconscious, it also confronts critique of Butler's notion of performativity. Nelson (1999: 349, 331) has criticized Butler for reducing subjects to 'unreflexive performers of dominant discourses', 'abstracted from personal, lived experience as well as from historical and geographical embeddedness'. While Ahmed concedes a certain degree of agency to her subjects by conceptualizing emotional performances as both conscious

\footnotetext{
${ }^{4}$ I use the parentheses to indicate that I refer here both to geopolitical and political storylines. I define geopolitical storylines as experiences that emerge from international political relations and violence whereas political storylines refer to political processes taking place within national boundaries.
}

and unconscious (see also footnote 2), her focus on the circulation of signs misses the situated domain of daily life in which emotions are negotiated, communicated and reinscribed (Wetherell, 2012: 160). Suggesting that the analysis of emotions should focus on how '[emotional] practices are situated and connected' (Wetherell, 2012: 13), Wetherell make a similar point as Tolia-Kelly (2006) regarding the need to situate emotional practices in time and place. Taking up the critique of Nelson, Wetherell and Tolia-Kelly, the (visual) ethnographic methodology employed in my research helps to embed the political subjects' emotional practices and their situated interactions with the audience in specific time-spatial contexts.

\section{Researching emotions}

Understanding emotions as performative requires focusing on the way in which both linguistic and embodied performances produce the spaces of campaigning and iteratively generate the political community they address. In order to capture both linguistic and embodied performances, I combined interviewing, participant observation and visual research.

First, interviews and recordings of political speeches served to analyze the new politicians' linguistic performances of emotions. Over 40 interviews with local female politicians ${ }^{5}$ and 20 political speeches of 17 local and 3 national candidates were recorded, transcribed and subsequently analyzed with regard to their content, the use of speech acts and the tonality of speech.

Second, extended fieldwork provided a valuable opportunity for sensing and discussing the emotions found during the campaigns. Between 2006 and 2010, I spent a total of 18 months in the provinces of Esmeraldas, Chimborazo and Orellana. I accompanied two prefects, two mayors and four councilors, all of them women, for several weeks in their everyday political activities and later on in their campaigning activities. Through this long-term engagement with these women, it was possible to address emotions not merely as an object of study but rather as 'a relational, connective medium in which research, researchers and research subjects are necessarily immersed' (Bondi, 2005: 433). In a second step, I contrasted the emotional performances of the observed local politicians with the populist campaign practices of national politicians in order to evaluate the extent to which their emotional performances generate different kinds of political communities. My comparison is based on my own observations of their (emotional) performances, informal conversations with citizens who attended these events and de la Torre's $(2008,2000,2010 a)$ extensive ethnographies of Abdalá Bucaram and Rafael Correa's campaigns in 1996, 2006, 2009.

Third, video taping many of the campaign events enabled me to capture minute details of the emotional performances of candidates and the audience and facilitated a close analysis of their body language afterwards (Schurr, 2012). My own visual data was complemented with video recordings of political speeches of (former) populist presidential candidates. While I agree with Simpson (2011: 343) that the video recording 'does not necessarily present or give a sense of the affective relations present in [...] encounters', visual data nevertheless can transmit the emotionality of certain spaces in a more effective way than written accounts. To offer an impression of the emotional atmosphere of local campaigning in Ecuador, some of these recordings are presented in linked files in the following sections.

\footnotetext{
${ }^{5}$ Semi-structured interviews were conducted with 40 local female politicians, among them 7 provincial candidates for the national assembly, 3 (vice)prefects, 3 (vice)mayors, 13 town councillors, 14 rural councillors as well as with 15 women heading local women's organisations. With regard to the ethnic composition of the interviewees, 8 of them self-identified as Afro-Ecuadorian, 12 as indigenous and the rest considered themselves to be mestizas.
} 
Examining the data and writing about the emotional geographies of campaigning in Ecuador, I was confronted with the challenge of how the actual feelings of candidates and audiences can be deduced from the (visual) recordings. While feelings are necessarily subjective and not easily shared, analyzed and interpreted, the analysis of the recordings with the female politicians themselves and two Ecuadorian colleagues at my home university offered the possibility to collaboratively approach the emotionality produced through political speeches.

\section{Performing emotions, generating political communities}

4.1. Together we suffer, together we hate: Of Waira pamushkas and perros del gobierno...

'To love and to serve el pueblo until it hurts and the more it hurts, the more I love you, compañeros [brothers and sisters]. This is Pachakutik, list 18! [...] We waste our time, quarrelling over a president who only takes notice [of our province] when we strike and when he needs oil, compañeros. That's why I invite all of you to consider carefully and decide which local authorities you trust, who [unlike other candidates] don't take advantage of the fact that a president, a presidential candidate is popular, trying to get onto the [party] lists like Waira pamushkas, ${ }^{6}$

trying to fish [for votes] to get elected, sometimes they are here only for a year or two, they think they can save our pueblo, compañeros, they even come to criticize our history of suffering, of sorrow, sometimes even of distress, compañeros. This isn't right, that's why you have to think about who you vote for!' (electoral speech, Guadalupe Llori, Prefect, 21 April 2009).

In the closing campaign speech on the final day of campaigning in the Amazon Province of Orellana, Prefect Guadalupe Llori explicitly addresses a number of emotions through her linguistic performance: love, suffering, sorrow, distress, mistrust. Looking at the way she aligns these emotions with certain bodies helps to understand how her campaign speech produces a political antagonism between the local branch of the (indigenous) Pachakutik party representing el pueblo - and the government party Alianza País. Llori contrasts the loving bodies of the Pachakutik candidates (marked through their membership of Pachakutik as indigenous and poor) with the careless and self-interested bodies of the government, personified in the mestizo, male body of Rafael Correa. Llori's speech act of interpellating president Rafael Correa and his local representatives as a waira pamushka and her hand gesture suggest an invasion from outside into the local territory (Video 1: http://www.youtube.com/watch? $v=T r E h p f i k V 8 M, \quad 0: 57-$ 1:00 min). Through this embodied speech act, she marks their bodies as white and threatening as the bodies of the colonizers and post-colonial elites who invaded the province from the colonial urban centers. Aligning his body with the body of oil in the province, she evokes past associations about colonial exploitation of natural resources, the people's labor and their natural environment. Feelings associated with the (post-)colonial experience, which are first only indirectly evoked by introducing the figure of the waira pamushka, are then explicitly recalled by referring to the province's history of suffering (see Fig. 1).

The campaign speech of Marco Santi, an indigenous candidate for the national assembly, at the same campaign event, links the

\footnotetext{
${ }^{6}$ In 2008, indigenous Mayor Auki Tituaña called President Rafael Correa 'the Waira pamushka of Ecuadorian politics' (waira pamushka: literally - son of the wind figuratively - people who appear out of nowhere)
}

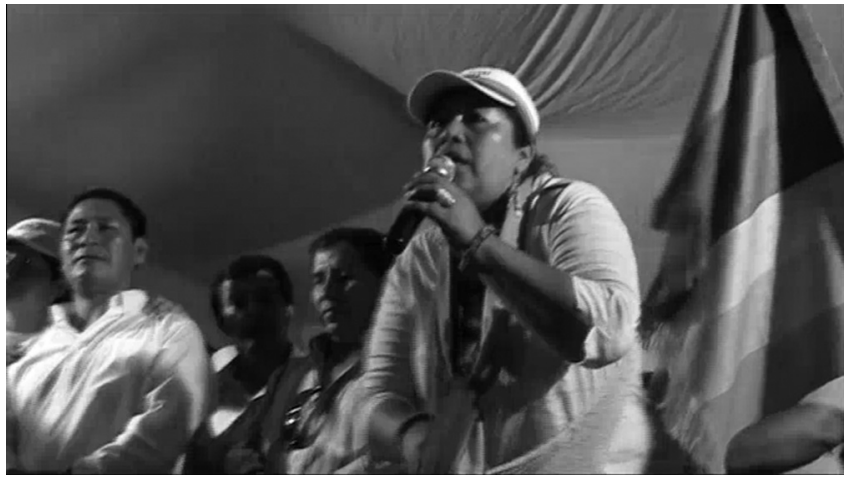

Fig. 1. Video Still Guadalupe Llori. Source: Video recorded by author.

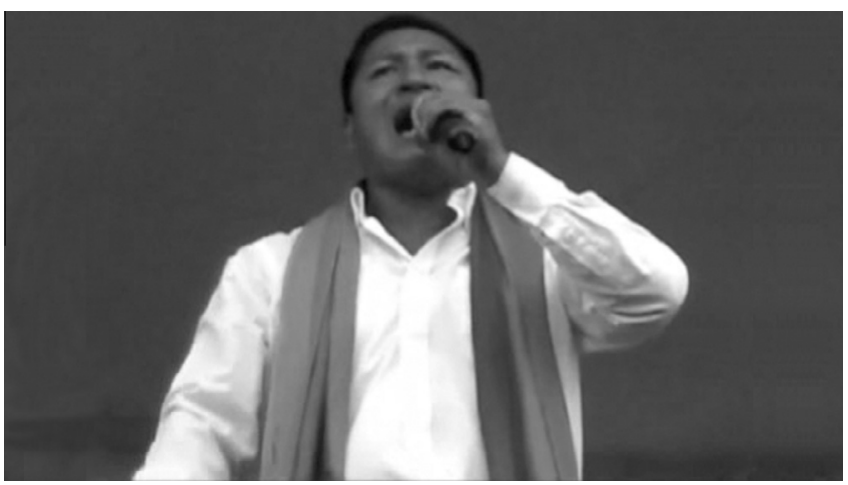

Fig. 2. Video Still from Marco Santi. Source: Video recorded by author.

past suffering even more directly with the province's recent history (see Fig. 2):

'Compañeros, it is true that we have had [political] authorities and sure they are here, watching the speech of a kichwa man from the Amazon. Learn your lesson and shout out loud! When they were authorities - I am referring to the "dogs" of the government, who must be here already - when they were authorities, what did they do? They turned their back on our brothers of Dayuma and they maltreated them. But there was a woman, [...] who turned in her body for the compañeros' (electoral speech, Marco Santi, candidate for the National Assembly, 21 April 2009).

Marco Santi emotionalizes this local space of campaigning and generates a situated political community by recalling - in a loud and impulsive voice - emotions of rabia (rage) linked to shared memories of the past event 'Dayuma'. In the context of the campaign in Orellana, it is not necessary to augment this term with a description or history. Marco Santi assumes that the word 'Dayuma' is enough to evoke feelings of injustice, exploitation, and suffering in the audience. 'Dayuma' stands for the detention of (indigenous) workers and Prefect Llori at the behest of President Correa during protests against a national oil company in the indigenous community of Dayuma (Comisión Veedora, 2008). The word evokes the event but also stands in for it, as part of the province's history of violence, suffering and injustice. The campaign speech exemplifies how the language of emotions operates through signs, conveying histories that involve exploited, maltreated and suffering bodies. Marco Santi's speech re-narrates this event in a specific way by sticking different emotions to the differently racialized and gendered bodies involved 
in this incident. When calling Correa and the local representatives of his party 'dogs of the government', their bodies are constructed as dangerous, menacing but also controlling and observing bodies. Accompanying these words with a gesture that points at some (imaginary) people observing the campaign event at the back of the crowd (Video 2: http://youtu.be/8zsq6Mvvlvk, 0:07-0:11 min), Santi evokes the image of dogs that guard a flock of sheep and establishes an analogy with the colonial machinery of surveillance. Feelings of anxiety, wrath and impotence resulting from colonial memories of violence are further recalled by highlighting in his speech and through his gestures (Video 2: http://youtu.be/8zsq6Mvvlvk, 0:41-0:44 min) that these dogs of the government have maltreated the brothers of Dayuma. The brothers (of the kiwcha man) being detained in the protests in Dayuma come to stand for the political community of Orellana as a whole. In both speeches, emotional performances of hate become performative in the sense that they draw on post-colonial histories of contact and racialize bodies in particular ways and hence 'make' and 'shape' bodies as forms of political action.

As I have discussed in the theoretical section, for the candidates' performances to be felicitous, the electorate needs to respond emotionally to them, aligning their bodies with or against other bodies into a political collective. The visual and auditive presence of the audience in these two video spots hint to the extent to which the candidates' emotional performances successfully generate the object of hate (the government party) and the affective community of local Pachakutik supporters. When Marco Santi talks about the 'dogs of the government' who maltreated the kichwa brothers, the crowd starts to boo and hoot down the political opponents, attributing feelings of disapproval and hate to the bodies of the government party (Video 2: http://youtu.be/8zsq6MvvIvk, 0:45$0: 48$ ). By sticking feelings of hate to the bodies of the government, the audience expresses a dominant feeling that circulates in the province:

'Orellana has always been exploited, first by the European colonizers, then by the oligarchic elites, international companies that extracted our wood and later our oil and especially by the [local and national] governments who got rich at the cost of the poor' (interview with a male representative of an indigenous organization, 20 March 2010).

The image of Orellana as an exploited pueblo - understood in the double sense of people and village - and emotions of rabia associated with this image are reproduced through these circulating references of Orellana's colonial past and by linking its present history to this past. While in many other provinces President Rafael Correa enjoys widespread support, the incident of Dayuma has aligned his body with colonial elites that mistreat the (indigenous) people of Orellana. Feelings of rage about the injustice the protesters in Dayuma faced play a central role in generating the people of Orellana into one imagined political community:

'We cannot permit the government to treat us like they have treated our brothers in Dayuma' (female participant of a workshop in the town hall, 5 February 2009).

The imagination that the person who has been detained illegitimately 'could-have-been-me' turns the detained person's anger into the anger of other citizens in Orellana (see Ahmed, 2004b: 130) and hence aligns the supporters of Pachakutik with each other and against the national government and their local representatives in a political collective. These emotions are not only stuck to different racialized bodies, but also to the particular place of Orellana as situated in the Amazon, far from the center of (post-)colonial power. The location of the province and its richness in natural resources such as natural rubber, precious woods and petroleum give rise to the particular power relations between the people of Orellana and the national government that determine the feelings present in the local campaign. As these emotions are closely linked to the particular history and place of the province in the Amazon, they generate a political community that is territorially bounded. Place-specific feelings associated with injustice, exploitation and neglect against the national government ('them') that is considered the source of these feelings aligns the Pachakutik supporter of Orellana in a local political community ('us').

\subsection{1. ... dominant gangs, vende patrias and pelucones}

The emotional storylines in the campaign in Orellana that generate a beloved local political community in distinction to the hateful bodies of the national governments reproduce the us-versus-them logic that are a crucial element of populist campaigning. de la Torre (1992, 2001, 2010a,b) shows that the main characteristic of populist campaigns is their Manichean rhetoric that pictures politics as a moral struggle between el pueblo (the people) and la oligarquía (established elites). El pueblo and la oligarquía thereby are social constructions that are constituted in different times and places through populist discourses in different ways. Analyzing in the following how populist presidents generate the collective of their opponents through feelings of rabia (rage), the paper sheds light on the way local politicians cite the Manichean emotional performances of populist campaigning.

Denouncing 'them' as 'dominant gangs, professional politicians, traffickers, and as selling off our homeland's honor' (Velasco Ibarra), 'vende-patrias' (selling out the homeland) (Abdalá Bucaram) or 'the pelucones ${ }^{7}$ who want to go back to the past' (Rafael Correa), populist presidents recall - just like the campaign in Orellena - past memories of exploitation of the country's (natural) resources by the Spanish colonizers. The political collective of los enemigos (the enemies/opponents), however, is far from being a stable, predefined collective. Correa, for example, has stuck his rage to very different bodies over the time of his presidency since 2007. Initially, all negative feelings were directed towards the whitened bodies of los pelucones, Ecuador's political and economic elites. Later on, the press became a target of his emotional tantrums when they started to criticize his government (Video 3: http://www.youtube.com/ watch?v=js-e2ZYZmJA). In 2010, Rafael Correa responded to indigenous movements' protests by calling them 'ponchos dorados' (gilded indigenous ponchos) and 'peluconería indígena' (indigenous wigs). He aimed to isolate the indigenous sector in its protests by aligning their indigenous bodies through the term 'pelucones indígenas' with the mainly white bodies of oligarchic elites who work against el pueblo. Citing this racist term, which was first used by conservative politicians in 1998 as reaction to indigenous people's increasing participation in electoral politics, he hopes to de-legitimize their claims by suggesting that the indigenous leaders no longer represent el pueblo. The following extract from a speech evidences the shift in Correa's construction of the menacing enemies of el pueblo:

'We have always said that the biggest danger for our political project, when we have successively defeated the right wing in elections, is the infantile leftism, the ecologism, the indigenism. The new conservative forces are exactly these ecological fundamentalisms and social organizations who don't represent anybody, but who think they represent el pueblo' (electoral speech, Rafael Correa, 19 January 2009, Quito).

This quote evidences both the shifting boundaries of the politi-

\footnotetext{
The term pelucones was used by President Correa to refer to the oppositional forces of the urban high-society in Guayaquil in a pejorative way. Translated pelucón means wig and comes from the time when the aristocratic members in the colonies wore wigs as did many aristocratic people elsewhere.
} 
cal collective of enemigos and the ambiguities of the term el pueblo. El pueblo does not simply express some kind of original popular identity, but is constituted through emotional performances that align people into a collective. When social movements that used to stand for el pueblo are delegitimized as not representing el pueblo, the term el pueblo needs resignification and space is opened for reconstructing a new order and new representatives of el pueblo.

Looking at Ecuador's recent history of popular protest that resulted in the overthrow of Abdalá Bucaram (1997), Mahuad Witt (2000), Noboa Bejerano (2002), and Lucio Gutiérrez (2005), the citizens' rabia against the political establishment becomes visible in the claim 'que se vayan todos' (throw them all out, see also introduction). In the same way as populist presidents have addressed (and generated) different political communities of opponents, the citizens' rage - expressed through protest chants like 'que se vayan todos' - is stuck onto different bodies. In the protests against President Mahuad, for example, the indigenous movement who aligned with the military directed their rage towards the political and economic elites, personified in President Mahuad. From his position as colonel, Lucio Gutiérrez played a crucial role in this popular protest through staging himself as one of el pueblo. In consequence, Lucio Gutiérrez was elected as president in the following elections. Three years later, the citizens' rage was redirected to the very body of Lucio Gutiérrez. Following corruption and the forceful dissolution of the court, nationwide mass protests reached a tipping point in April 2005 when Gutiérrez labeled protestors in Quito forajidos (criminals, outlaws) (Platán, 2005). Through his derogatory speech act, a new political community, los forajidos, was generated. In Quito's streets indigenous bodies aligned with the mestizo bodies of Quito's middle class into one community when forcefully shouting 'we are all forajidos', drumming on pots, demanding that Gutiérrez resign. Aligning his body with the bodies of former corrupt presidents like Noboa, Mahuad and Bucaram (Fig. 3) into one political community, they stuck the same feelings of rabia onto his body that they had expressed towards his predecessors before.

The episode of citizens' emotional responses to Lucio Gutiérrez shows that the emotional interactions between citizens and politicians generate antagonistic political communities whose boundaries are constantly shifting in response to political events. While citizens need to respond to and reproduce the emotional performances of campaigning politicians to bring them into office, once they redirect negative emotions from political opponents towards the one they formerly supported, these emotions have the power to bring about political changes.

\subsection{Loving el pueblo, because one is el pueblo}

Love for el pueblo is the complementary emotion to the hate for los enemigos in a populist Manichean rhetoric. The campaign speech of

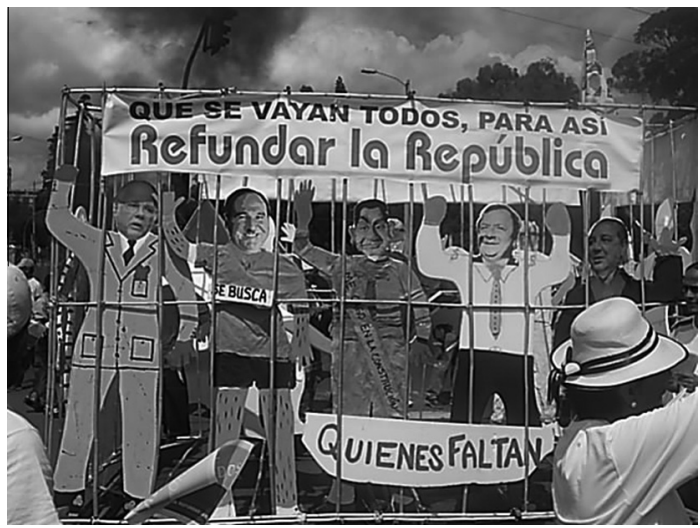

Fig. 3. Protests against Lucio Gutiérrez. Source: Own picture.
Guadalupe Llori (Video 1: http://www.youtube.com/watch?v=TrEhpfikV8M) opens with her declaration of love for her pueblo. In her speech, she defines her pueblo (in the double sense of people and village) along territorial boundaries as those who live in the province. Emphasizing in the welcoming of every speech that she greets 'the women and men of Orellana, her indigenous brothers and sisters, los colonos [mestizo urban settlers who migrated to the Amazon], los blancos [white people], mestizos, negros [people of Afro-descendants]', she aims to include those into her political community who have been denied political rights and participation in (post)colonial times. In including explicitly ethnic minorities and women into her community, she follows the trend of populist politics whose central achievement has been to open up the narrowly defined and highly exclusive boundaries of institutionalized politics in Ecuador.

Ecuador's history of populism shows how populist leaders have gradually expanded the boundaries of their beloved pueblo. For the first populist president Velasco Ibarra (1934-1935, 1942-1946, 1952-1956, 1960-1961, 1968-1972), el pueblo - his famous chusma (rabble) - represented the literate lower mestizo classes, but excluded illiterate (mainly indigenous and Afro-Ecuadorian) men and women who were not eligible to vote (Sosa-Buchholz, 2010: 48). In contrast, Abdalá Bucaram, who campaigned in the 1980s after universal suffrage was introduced by the new constitution of 1979 , expanded the concept of el pueblo towards the newly enfranchized illiterate. While his campaign videos (Video 4: http://youtu.be/ DAUKYommNck, Figs. 4 and 5) show his affective gestures towards indigenous and Afro-Ecuadorian people, he portrayed el pueblo in his speeches as the urban and mestizo poor (Freidenberg, 2007). President Rafael Correa (President since 2007) campaigned with the slogan 'la patria ya es de todos' (the fatherland now belongs to

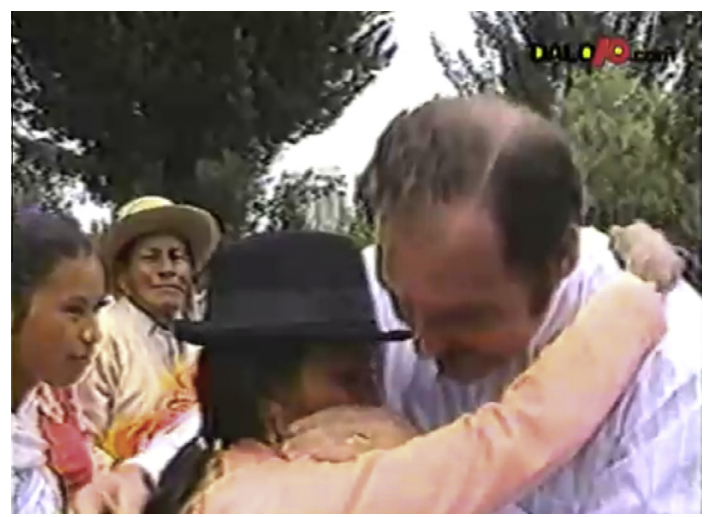

Fig. 4. Video Still from video Bucaram. Source: Stills from video Bucaram.

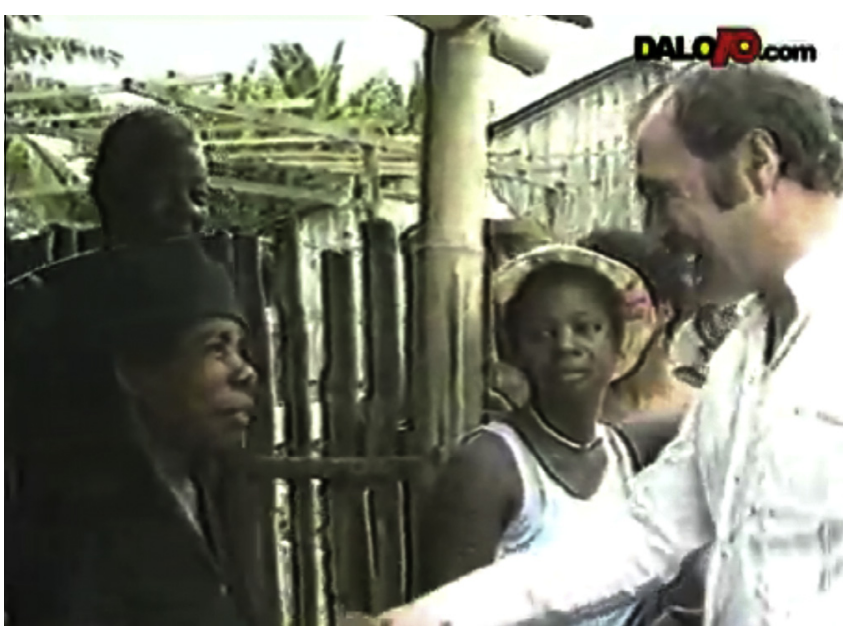

Fig. 5. Video Still from video Bucaram. Source: Stills from video Bucaram. 
all). Many campaign spots of his party Alianza País picture this multicultural diversity of el pueblo through their affective footage (Video 5: http://www.youtube.com/watch?v=08HfvvCyvg8, Figs. 6-8).

To represent el pueblo - defined through shifting boundaries - is a central claim by new political subjects and populists alike through which they hope to distance themselves from former politicians and regain the constituents' trust. The attempt of populist

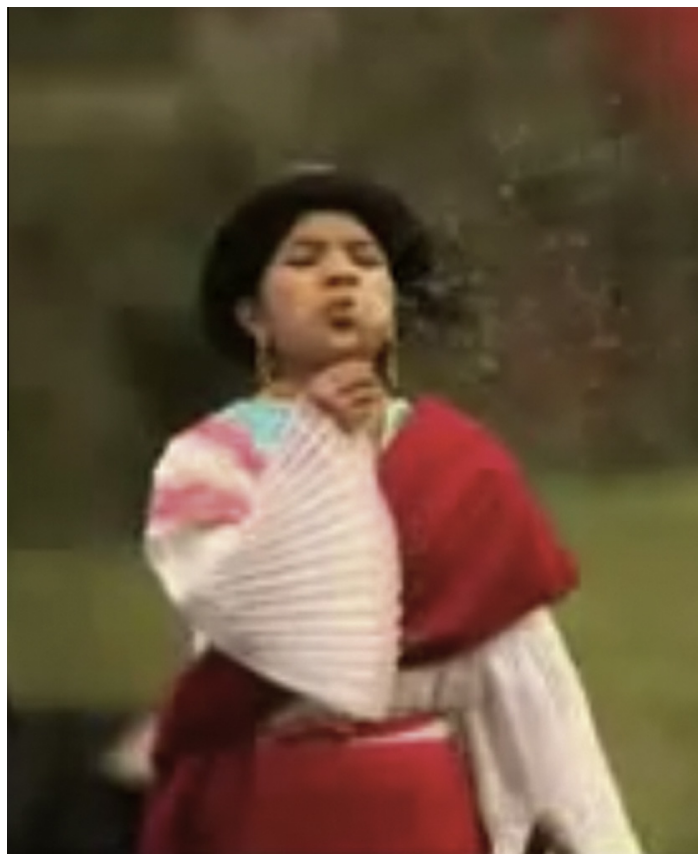

Fig. 6. Indigenous woman in campaign spot. Source: Stills from campaign spot Rafael Correa.

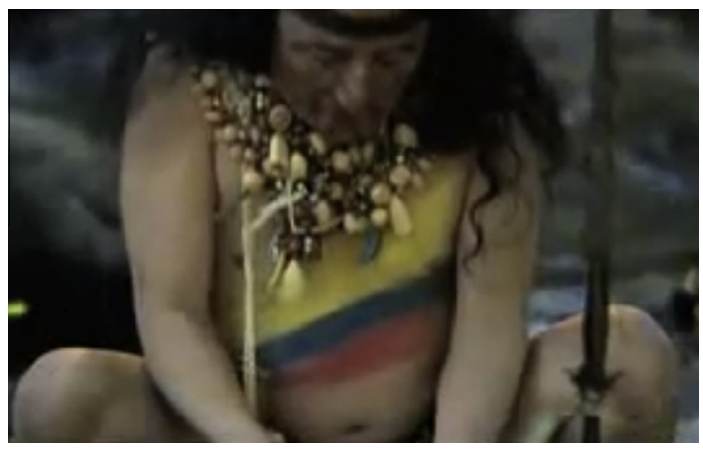

Fig. 7. Indigenous man in campaign spot. Source: stills from campaign spot Rafael Correa.

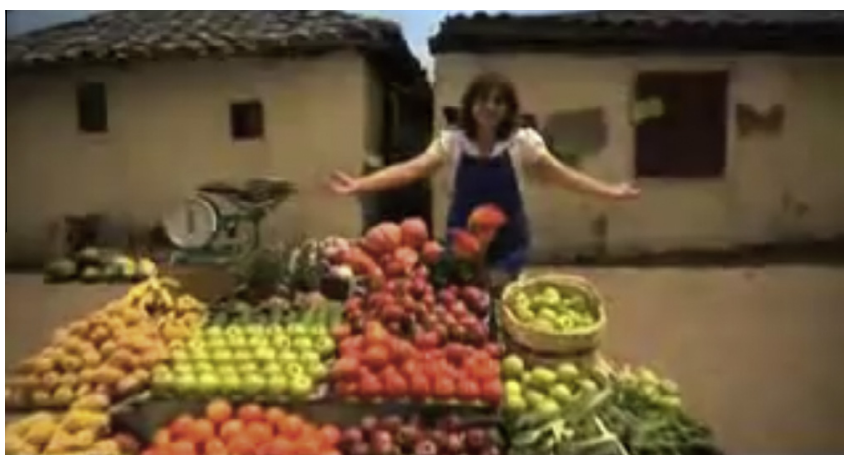

Fig. 8. Chola woman in campaign spot. Source: Stills from campaign spot Rafael Correa. and new political subjects to position themselves as one of el pueblo is most evident in their way of clothing. Through wearing casual clothes, Guadalupe Llori constructs herself as one of el pueblo in a similar way as the guayaberas (men's shirt-jac) of Abdalá Bucaram (President 1996-1997), the farmer shirt and baseball cap of Lucio Gutiérrez (President 2003-2005) or Rafael Correa's jeans jacket (President since 2007) move the national presidents closer to el pueblo (Figs. 9-11).

While the use of black suits, white shirts and ties is associated with the masculine and white bodies of (post-)colonial elites, the casual clothing of both new and populist politicians represents their bodies as classed and racialized in a similar way as the common body of the mestizo pueblo. By adopting indigenous traditional cloth and using attire in the rainbow color of the indigenous Whipala flag, both populist politicians and local politicians like Guadalupe Llori further racialize their mestizo bodies as indigenous in order to align their bodies with the bodies of their indigenous electorate (see Figs. 12-14).

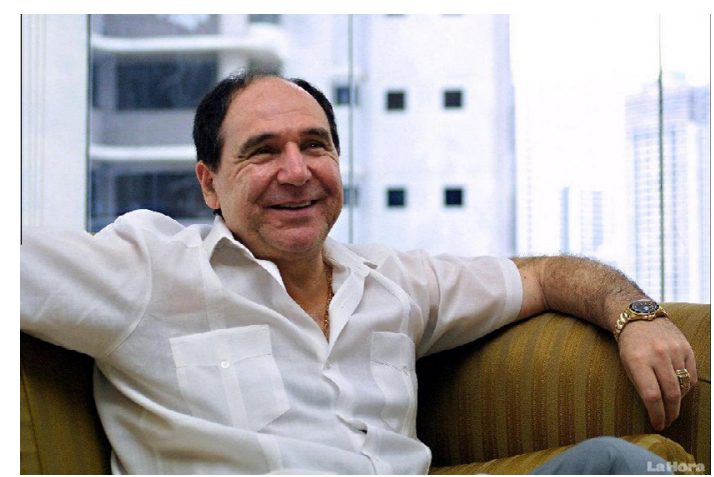

Fig. 9. Populists wearing casual clothes, representing el pueblo. Abdalá Bucaram. Source: www.economist.com/node/3849743.

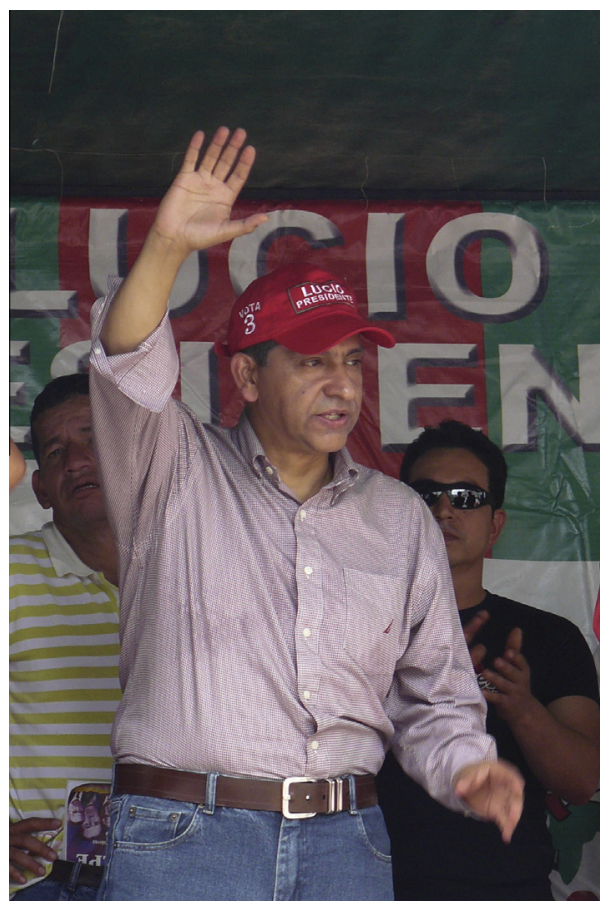

Fig. 10. Populists wearing casual clothes, representing el pueblo. Lucio Gutiérrez. Source: Own picture, Campaign in Francisco de Orellana. 


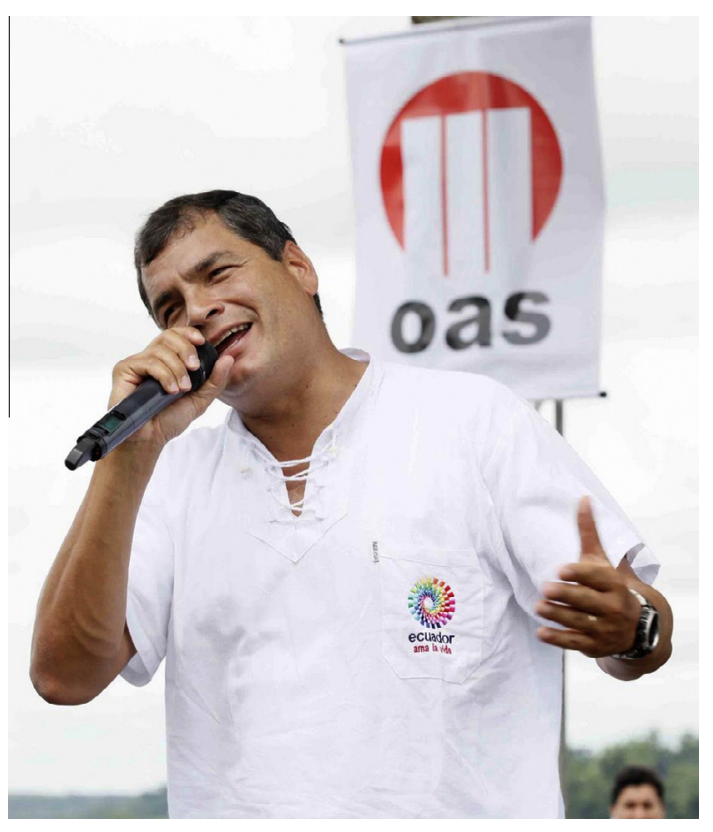

Fig. 11. Populists wearing casual clothes, representing el pueblo. Rafael Correa. Source: http://www.laprogressive.com/hugo-chavez-rafael-correa/.

Through their choice of dress both populist and new political subjects aim to evoke feelings of belonging, trust and amor by positioning themselves as 'one of el pueblo'. Picturing oneself successfully as one of el pueblo plays a central role in establishing trust with the constituents:

'He [Lucio Gutiérrez] was born of humble origins, and I am also from humble origins ... I trusted Gutiérrez' (Reel 2005: A13).

'Lupita [Guadalupe Llori] is one of el pueblo, she used to be a taxi driver, that's why I love her' (interview with a mestiza woman, 03 April 2009).

On the basis that they share a common (class) background, constituents feel that they are rather able to align their bodies with populist and new political subjects than with former political elites. To further strengthen emotional relationships of love and trust, both new and populist candidates picture el pueblo as a family. Bucaram, for example, 'promised to create a family [...] under his patriarchal protection', because he 'loved the poor, he would

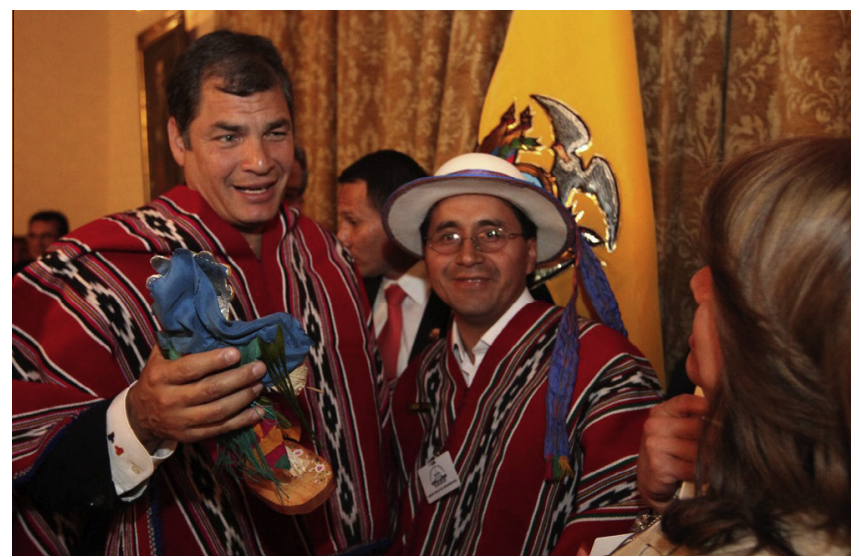

Fig. 12. Use of indigenous ponchos and symbols in the campaign. Rafael Correa. Source: Facebook/Correa.

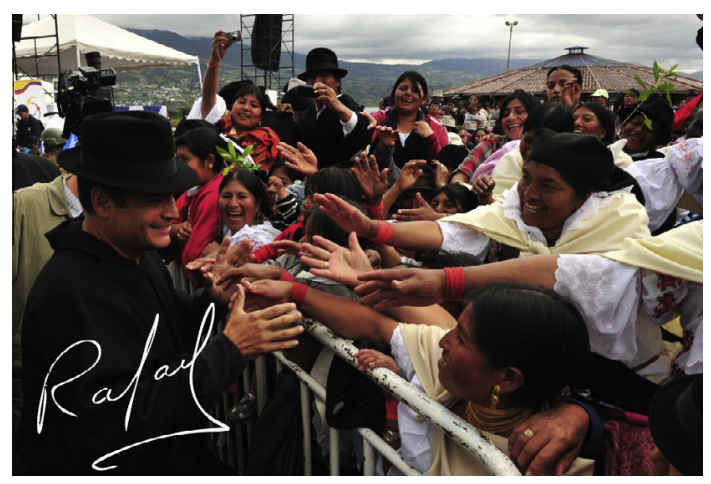

Fig. 13. Use of indigenous ponchos and symbols in the campaign. Rafael Correa. Source: Facebook/Correa.

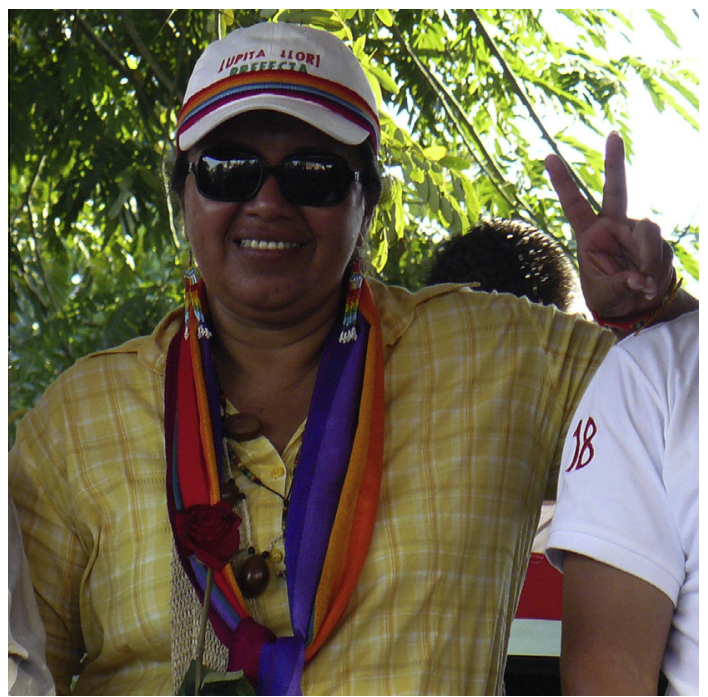

Fig. 14. Use of indigenous ponchos and symbols in the campaign. Guadalupe Llori. Source: Own picture.

protect them by becoming their father' (de la Torre, 2010a: 94). Rafael Correa generates his multi-cultural Ecuadorian family when interpellating differently racialized citizens as brothers as the following quote from a speech shows:

'A big hug of Patria Nueva [the government party], of new spirit, trust in tomorrow and amor, a brotherly hug, an affective hug for all of you [both masculine and feminine form], for our migrant brothers, for the workers, peasants, housewives, professionals, informal merchants, cholos [an urban indigenous person], negros [Afro-Ecuadorians], students, montubios [peasants of the Coast], indios, whites, mestizos,...' (Speech Rafael Correa for the third anniversary of the citizen revolution, 19 January 2009, Quito).

He hugs all these bodies both verbally and with his body - just as one would hug family members - when embracing his supporters in campaign events (Figs. 15 and 16), aligning all these bodies that are racialized, ethnicized and classed in different ways through his affective interpellation in one political collective.

In a similar way the local candidates in Orellana hope for people's loyality as if they were family members. They picture the local electorate as a family by stating that they are 'a kichwa Amazonian brother' (Marco Santi), 'a daughter of the Canton' (Maggali Orell- 


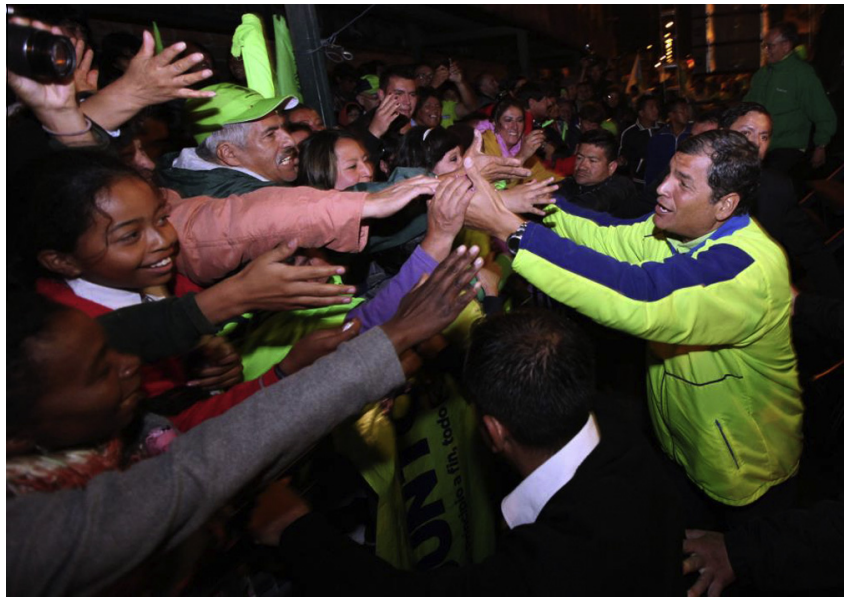

Fig. 15. Rafael Correa touching his supporters in an electoral campaign. Source Facebook/Correa.

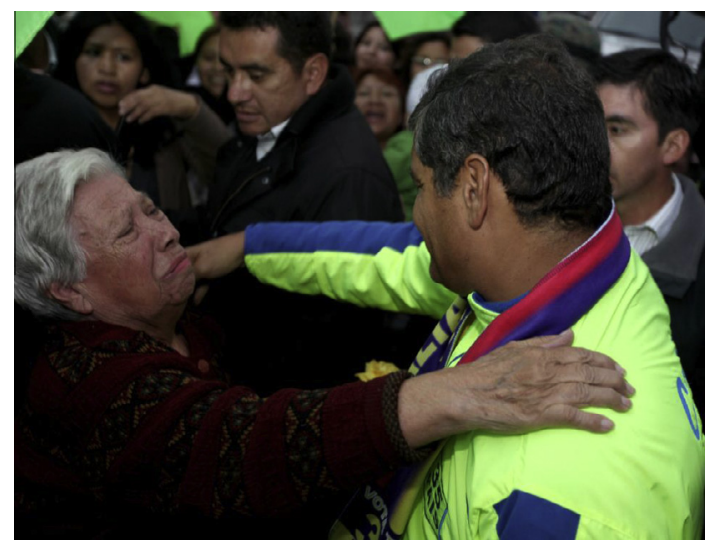

Fig. 16. Rafael Correa hugging a female supporter. Source: Facebook/Correa.

ana), or 'the mother of Coca' (Anita Rivas). In particular, Prefect Guadalupe Llori and Mayor Anita Rivas portray themselves as 'mothers of el pueblo' and frame their political relationship with the people in terms of a politics of care:

'Orellana is un pueblo [in the double sense of people and village] blessed by God and damned by the [local and national] governments. Nobody cared for this pueblo. Anita and I are the first to truly love this pueblo, because we know the suffering of the people, because unlike most other politicians, we have grown up here, we are daughters of Orellana' (interview Guadalupe Llori, 17 February 2010).

Prefect Guadalupe Llori and Mayor Anita Rivas stage themselves as representatives of the people arguing that only those who grew up in the same territory can truly represent el pueblo of Orellana. In so doing, they stimulate emotions in the audience by discursively constructing el pueblo as a local collectivity that is closely linked to the particular place and history of Orellana. The comparison between the campaign practices of local politicians and national presidents has shown that both populist and new political subjects have expanded the boundaries of el pueblo over time by addressing formerly excluded social sectors through their emotional performances of love. At the same time, their emotional performances that define the boundaries between the antagonistic political communities of el pueblo and the opponents are situated in time and place. While populist presidents situatively have shifted the boundaries of el pueblo, the local politicians in Orellana generate the political community of their supporters on basis of their territorial belonging and the specific (post-)colonial history of the province.

\subsection{1. ... loving el pueblo until it hurts}

The populist Manichean rhetoric introduces a third trope in the emotional relation between el pueblo and la oligarquía: the redeemer personified in the populist leader. de la Torre's (2010a: 93) ethnography of Abdalá Bucaram's campaign in 1996 shows how the figure of the redeemer is performed in populist campaigns: 'He jumped off the platform after each speech and walked through the masses. The audience tried to touch their leader, who, like Christ, touched the people to heal and redeem them'. A self-promoting video of Bucaram represents him as the savior of the poor, showing him even in the posture of a crucified Jesus (Video 6: http://www.youtube.com/watch?v=N5egRz2RJW8). The image implicates that Bucaram - just like Jesus - sacrificed his life for his pueblo when he was exiled to Panama (see Fig. 17-19).

While Rafael Correa used to distance himself clearly from 'los políticos de siempre' [the traditional political elites] like Bucaram, his campaign consecrates politics and stages him as a Christian leader in a similar way. With the new constitution - instead of the bible - in the hand, he is the one who brings justice to el pueblo. He stages his socialist revolution as a time of light, whereas the past is pictured as el oscuro (darkness), night or nightmare as the following campaign propaganda shows (see Fig. 20):

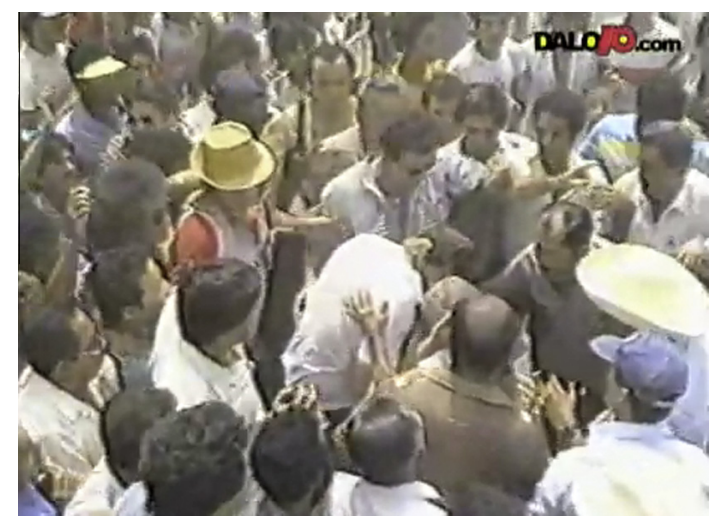

Fig. 17. Bucaram 'bathing' in the crowd. Source: Stills from Campaign Spot Bucaram.

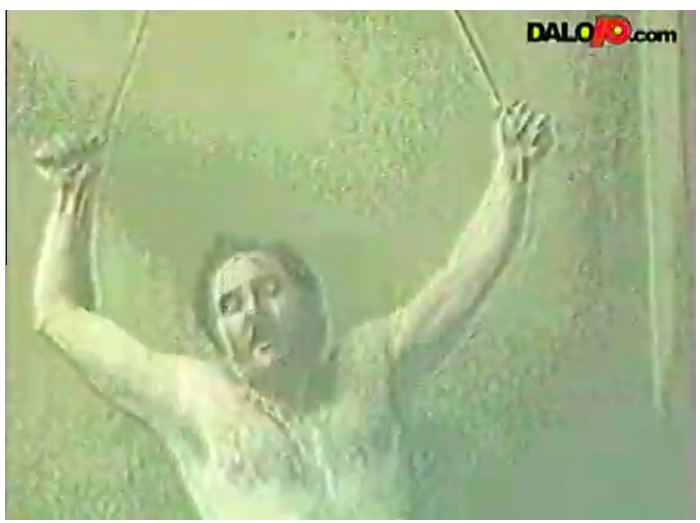

Fig. 18. Bucaram crucified. Source: Stills from Campaign Spot Bucaram. 


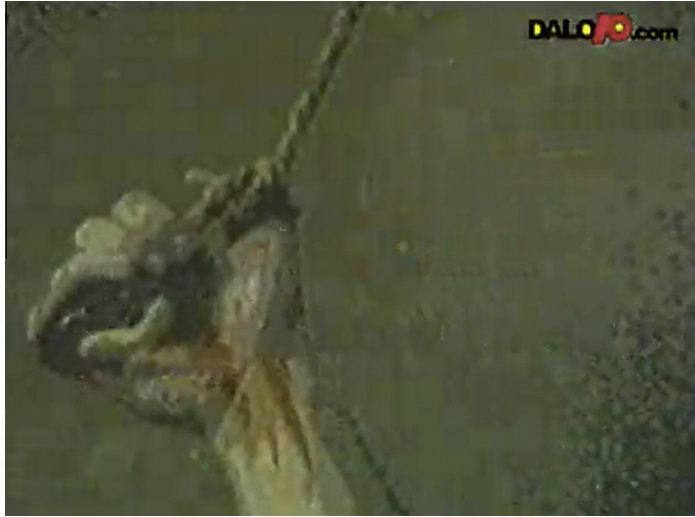

Fig. 19. Bucaram crucified. Source: Stills from Campaign Spot Bucaram.

In so doing, he frames his campaign within biblical parables when announcing that a new dawn has arisen after a long night, just as it is narrated in the story of Noah's ark or when talking about sharing the bread.

This religious element of a politics of redemption can also be found in the local campaign in Orellana. When Marco Santi renarrates in his speech that his oppressed (indigenous) brothers were rescued by 'a woman, [...] who turned in her body for the compañeros', he positions Guadalupe Llori as a martyr. In picturing Llori as a Christ-like redeemer who released the humble people from suffering and poverty, Santi draws on the same religious storyline employed by populist presidents. Staging Llori as the redeemer of the (indigenous) pueblo of Orellana, he aligns the bodies of the indigenous people in Orellana with Guadalupe Llori in one political community. Her sacrifice evokes devotion and loyalty in el pueblo, binding the bodies of the (racialized) pueblo together with Llori's body (and those of her party) in a paternalistic, quasi-religious relationship. Christian faith and spirituality in general play a central role in forging the political community of Pachakutik supporters, aligning subjects with each other that -similar to the evangelical-capitalist coalition in the US (Connolly, 2005) - have different economic interests.

The figure of the martyr is reproduced in her own campaign speech when she states: 'to love and to serve el pueblo until it hurts and the more it hurts, the more I love you' (Video 1: http:// www.youtube.com/watch?v=TrEhpfikV8M, 0:00-0:10 min). This idea draws on the Andean concept of amor serrano, which refers to the way (indigenous) men frame and justify their violence against women as part of their romantic relationship with women (see Mitchell, 2006). Llori inverts the typical saying of the amor serrano 'if he doesn't hit you, he doesn't love you' (Van Vleet, 2002:

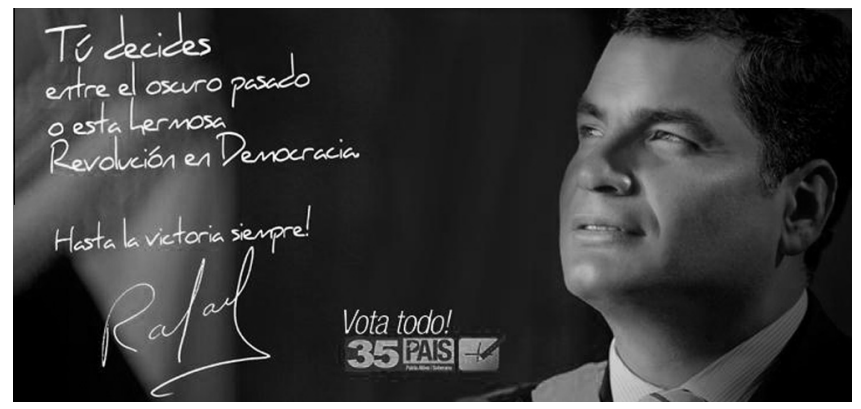

Fig. 20. Campaign propaganda Rafael Correa (Translation: You decide between the darkness of the past and this beautiful democratic revolution). Source: http:// mpaisloja.blogspot.ch/2009/04/tu-decides-entre-el-oscuro-pasado-o.html.
576) on the basis of her experience that loving and serving her people resulted in a lot of suffering during her imprisonment. Hence, suffering for el pueblo and risking her own life for el pueblo prove her amor for el pueblo. She generates el pueblo through this statement on the ground of her sacrifice for the people of Orellana. The indigenous people she defended stand here for the incarnation of el pueblo. In Orellana, gratitude, admiration and love dominate the citizens' emotional relationships towards their political leaders:

'Of course I support Guadalupe, she went to prison for us, she fought for the dignity of our pueblo, she turned this pueblo de nadie (no man's land), this nido de lodo (armpit) into a beautiful town, the streets are asphalted now, she gave our pueblo an identity' (short interview with a mestiza woman, 15 April 2009).

The province's particular history as an Amazon town situated far from the center of economic and political power and connected feelings of neglect, resentment, and deprivation of rights are crucial for forming the sense of community in Orellana. In the view of many, 'Guadalupe has made great sacrifices for the people of Orellana as she defended the rights of the province' (conversation with a male street vender, 3.3.2009). Just as the politics of redemption of populist presidents has transformed politics into paternalistic relations, Guadalupe Llori demands loyalty from her pueblo, because she has made all these sacrifices for her pueblo. In so doing, the political space Guadalupe Llori constructs is like populist spaces of campaigning closely linked to spiritual and religious spheres where love and devotion are exchanged for redemption and salvation.

4.3. We love her, because she is different from los políticos de siempre (is she really?)

The Ecuadorian history of populism shows that populist leaders - in a similar way to new political subjects - have gained power through their role as martyr as well as being considered an outsider who does not belong to the political establishment. For many, these outsiders are the only ones they can possibly trust as the political crisis in Ecuador in the 1990s resulted in a growing detachment of the electorate from traditional parties (Mainwaring and Scully, 1995). In the view of voters, the authenticity of candidates like Guadalupe Llori, Marco Santi as well as populists like Rafael Correa or Lucio Gutiérrez rests on their emergence from social movements. Authenticity, which is related to candidates' relations to social movements, is an important asset for winning elections in the context of Ecuadorian politics. The organizational support of social movements is here as important as being able to perform successfully one's role as one of el pueblo.

'I just can't help it, Lupita's [the Prefect of the province] speeches just make me cheer, I really adore her. Her passion for el pueblo.is so authentic, she is our real leader - she is just so different from these politicos de siempre [typical politicians, male form]' (a female supporter in a campaign event in Francisco de Orellana, 21 April 2009).

What calls attention in this quote is the speaker's reference to 'authenticity'; because Guadalupe Llori's performance is authentic, she is considered the 'real' leader. An alignment with her - both in the sense of being (emotionally) close to her and voting for her becomes possible, because she is different from the other (read: male, populist) politicians. This phenomenon is typical of many of the new political subjects. Because they are perceived rather 
as representatives of social movements than as political authorities, voters feel they are 'truer', better, and more responsive representatives of el pueblo.

While the emotional relation between candidates and electorate in the case of populist und new political subjects is built to some extent on clientelistic and paternalist relationships, this quality dominates the emotional bond between voters and populists like Bucaram, Noboa and Gutiérrez, as the quote from a female Bucaram supporter shows:

'I love my party. [...] My heart asks me to be roldista (party of Bucaram) and I will be one until God calls me back home. Why? [...] The President has helped all of us to find a job. He has given us a job. This is why people join the party' (cited in Freidenberg, 2007: 155, author's translation).

While this Bucaram supporter frames her clientelist relationship with Bucaram in terms of love, others have a more pragmatic approach:

'Correa hasn't given [us] anything, but Alvarito sí [but Alvaro Noboa, yes]' (cited in de la Torre and Conaghan, 2009: 349).

For people living in precarious conditions, electoral campaigns are considered moments of hope, as populist leaders facilitate access to resources, land and problem-solving networks. Hence, the relationship between populist leaders - including local politicians like Guadalupe Llori - and associated feelings of love, gratitude and loyalty are linked with poor people's everyday needs and lack of access to resources. Participation in electoral campaigns hence is often a strategic step for citizens and mutual performances of love often mask relations of domination between politicians and the poor. de la Torre (2010a: 169) shows that followers often had a different reading of Bucaram's performances and did not necessarily respond emotionally with the same quality of love he expected:

'Common people attended their rallies out of curiosity, or in order to enjoy a free show and have a good time, but not because they supported the self-proclaimed leader of the poor'.

The entertaining character of campaigns mentioned in the quote plays an important element in both motivating followers to attend public rallies but also in aligning the bodies of el pueblo with each other while enjoying music, dance and drinks offered in these events.

While the emotional performances of candidates play an important role in interpellating a political community of supporters, their concrete achievements determine whether the citizens will align in this political collective in the long run. The history of overthrown populist presidents like Abdalá Bucaram or Lucio Gutiérrez shows that the emotions of el pueblo can change rapidly, when they feel no longer represented by a populist leader or no longer perceive his/her emotional performances as authentic. When politicians transform in people's perspective from 'being one of us' and hence an 'authentic' leader into a político de siempre, they move their bodies away from the respective leader. In a similar way, as (moral) support for indigenous politicians of the Pachakutik party has decreased in recent years (Tuaza, 2009), Guadalupe Llori has faced increasing distrust since the incidence of Dayuma. She was confronted with similar reproaches of having abused her power as many indigenous leaders, who are accused of enriching themselves at the cost of the poor and not representing the social movement anymore. After Llori's long detention people often doubted her innocence:

'I have supported Lupe, I have voted for her to become mayor, to become prefect. But now,... people say she has bank accounts in Spain, she has a hacienda, sometimes I think she is bribed by the compañias [international oil companies]. Now, she is just like los políticos de siempre' (informal conversation with a local entrepreneur (male, mestizo), 02 February 2009).

Turning into a político de siempre, Guadalupe Llori loses her capacity to embody (the will of) el pueblo, and hence her authenticity and political legitimacy. In a similar way as Rafael Correa has come to embody el pueblo after (indigenous) social movement leaders lost credibility, new (populist) leaders will emerge in Francisco de Orellana to follow in Guadalupe Llori's footsteps. El pueblo will be constructed in new ways by this politician to come who claims to embody it, aligning the bodies of the Orellanenses into different antagonistic political communities.

\section{Towards an emotional electoral geography}

'The world of politics is inevitably and rightly a world full of emotions' (Clarke et al., 2006: 5).

The case study of Ecuadorian campaign practices underscores the importance of emotions in the constitution of electoral spaces. On an empirical level, the analysis of emotional campaign performances is crucial to understanding contemporary politics in Ecuador. An emotional electoral geography thus must go beyond the mere analysis of electoral results to understand how emotional campaign performances establish affective relationships with the constituents and generate political communities. Comparing the emotional campaign practices of populist presidential candidates with those of so-called new political subjects in a local campaign in Orellana, the study has shown that these different political subjects employ similar emotional patterns. Aligning rabia (rage) with the whitened bodies of the enemies of el pueblo (the people), while constructing the emotional relationship between el pueblo and themselves as full of amor (love), hate and love become the dominant emotions to create the very political communities of el pueblo and the enemies they address. Following years of political instability and distrust in political institutions, both populist and new political subjects hope to gain trust and confidence from the constituents by aligning their bodies with the bodies of el pueblo through a politics of redemption in which the political leader figures as the redeemer of el pueblo, sacrificing her/his life for el pueblo. The different political subjects, however, stick emotions of hate and love to differently racialized and classed bodies. In consequence, the boundaries of the resulting political communities of el pueblo and los enemigos shift over time and space.

On a conceptual level, the paper theorizes political communities as performatively generated through emotional campaign performances and interactions. Introducing Sara Ahmed's notion of performative emotions to electoral studies, the paper sheds light on the way political communities are produced in campaign performances. The employed performative approach to emotions has focused attention on the way emotional performances iteratively cite certain storylines about (post-)colonial exploitation and exclusion, political corruption or class struggles. These storylines evoke collective memories and shared feelings, aligning the bodies of the performing politician(s) and the constitutents with each other into one political collective against the bodies of los enemigos, to which negative of emotions of distrust, rage and hate are stuck to. The paper has shown the importance of understanding the emotions observed in campaigns as being generated by, and expressive of, the particular (historical) context in which constituents live. Hence, it calls for the need to embed emotional electoral geographies in theories of difference.

On a methodological level, the paper argues that the shift towards a more grounded, embodied, and emotional electoral geography makes it necessary to rethink the positivist approach applied 
in most studies in electoral geography and political science. I have suggested a methodological framework that combines qualitative methods with (visual) ethnography as a way of capturing both speech and body acts that bring into being emotional spaces. Employing visual methods, this paper has aimed to focus on both the linguistic and embodied performances of emotions in political spaces. In this sense, an emotional electoral geography must not only bring in new aspects such as emotions and bodies into electoral geography, but creatively engage with a wide set of methods.

\section{Acknowledgements}

First, I would like to thank all the women I worked with in Ecuador, especially those I accompanied in their everyday political activities and during their electoral campaign. Thanks to Lynn Staeheli, Benedikt Korf, Martin Müller, Jonathan Everts, and three anonymous referees for careful comments on drafts of this article. I am grateful for funding from the Swiss National Science Foundation (SNF) and the support received within the Graduate School "Gender: Prescripts and Scripts" hosted at the Interdisciplinary Centre of Gender Studies at the University of Bern.

\section{Appendix A. Supplementary material}

Supplementary data associated with this article can be found, in the online version, at http://dx.doi.org/10.1016/j.geoforum.2013. 05.008.

\section{References}

Agnew, John, 1990. From political methodology to geographical social theory? A critical review of electoral geography, 1960-1987. In: Johnston, Ron, Shelley, F. Taylor, Peter (Eds.), Developments in Electoral Geography. Croom Helm, London, pp. 15-21.

Ahmed, Sara, 2004a. Collective feelings. Theory, Culture \& Society 21 (2), 25-42.

Ahmed, Sara, 2004b. The Cultural Politics of Emotion. Edinburgh University Press, Edinburgh.

Alcoff, Linda., 1991. The problem of speaking for others. Cultural Critique 20, 5-32. Ansolabehere, Stephen, Iyengar, Shanto, 1995. Going Negative. How Attack Ads Shrink and Polarize the Electorate. The Free Press, New York.

Austin, John L., 1962. How to Do Things with Words. Oxford University Press, Oxford.

Blunt, Alison, Rose, Gillian, 1994. Writing Women and Space. Colonial and Postcolonial Geographies. Guilford Press, New York

Bondi, Liz., 2005. Making connections and thinking through emotions: between geography and psychotherapy. Transactions of Institute of British Geographers 30, 433-448.

Butler, Judith, 1993. Bodies that Matter: On the Discursive Limits of "sex". Routledge, New York

Butler, Judith, 2004. Undoing Gender. Routledge, New York.

Butler, Judith, 2010. Performative agency. Journal of Cultural Economy 3 (2), 147161

Cañete, María Fernanda, 2004. Las vicisitudes de la aplicación de la cuota electora en los partidos políticos. In: Cañete, María Fernanda (Ed.), Reflexiones sobre mujer y política. Memoria del seminario nacional "Los cambios políticos en e Ecuador: Perspectivas y retos para las mujeres". Abya-Yala, Quito, pp. 59-70.

Clarke, Simon, Hoggett, Paul, Thompson, Simon, 2006. Emotion, Politics and Society. Palgrave Macmillian, New York.

Connolly, William E., 2005. The evangelical-capitalist resonance machine. Politica Theory 33 (6), 869-886.

Conway, Janet, 2008. Geographies of transnational feminisms: the politics of place and scale in the world march of women. Social Politics: International Studies in Gender, State and Society 15 (2), 207-231.

Cupples, Julie, 2009. Rethinking electoral geography: spaces and practices of democracy in Nicaragua. Transactions of the Institute of British Geographers NS 34 (1), 110-124.

de la Torre, Carlos, 1992. The ambiguous meanings of Latin American populisms. Social Research 59 (2), 385-414.

de la Torre, Carlos, 2000. Populist Seduction in Latin America. The Ecuadorian Experience. Ohio University Press, Ohio.

de la Torre, Carlos., 2001. Redentores populistas en el neoliberalismo: Nuevos y viejos populismos Latinoamericanos. Revista Espanola de Ciencias Políticas 4, 171-196.

de la Torre, Carlos, 2010a. Populist Seduction in Latin America, second ed. Ohio University Press, Ohio.

de la Torre, Carlos, 2010b. Rafael Correa un Populista del Siglo XXI. Latin American Network Information Center, pp. 1-33. de la Torre, Carlos, Conaghan, Catherine, 2009. The hybrid campaign: tradition and modernity in Ecuador's 2006 presidential election. The International Journal of Press/Politics 14 (3), 335-352.

Dowler, Lorraine, Sharp, Joanne, 2001. A feminist geopolitics? Space and Polity 5 (3), $165-176$.

England, Kim., 2003. Towards a feminist political geography? Political Geography 22, 611-616.

Fluri, Jennifer L., 2011. Bodies, bombs and barricades: geographies of conflict and civilian (in)security. Transactions of the Institute of British Geographers 36 (2), 280-296.

Freidenberg, Flavia, 2007. La tentación populista: Una vía al poder en América Latina. Editorial Síntesis, Madrid.

Goldstein, Kenneth M., Holleque, Matthew, 2010. Getting up off the canvass: rethinking the study of mobilization. In: Leighley, Jan E. (Ed.), The Oxford Handbook of American Elections and Political Behavior. Oxford University Press, Oxford, pp. 577-594.

Gregson, Nicky, Rose, Gillian, 2000. Taking Butler elsewhere: performativities, spatialities and subjectivities. Environment and Planning D: Society and Space 18 (4), 433-452.

Gruszczynska, Anna., 2009. "I was mad about it all, about the ban": emotional spaces of solidarity in the Poznan March of Equality. Emotion, Space and Society 2 (1), 44-51.

Hampton, Samuel, 2009. Performance and rhetoric: assessing political speech. Affect 1, 3-25.

Hyndman, Jennifer, 2001. Towards a feminist geopolitics. The Canadian Geographer $45,210-222$.

Hyndman, Jennifer, 2004. Mind the gap: bridging feminist and political geography through geopolitics. Political Geography 23 (3), 307-322.

Johnston, Ron, Pattie, Charles, 2004. Electoral geography in electoral studies: putting voters in their place. In: Barnett, Clive, Low, Murray (Eds.), Spaces of Democracy: Geographical Perspectives on Citizenship, Participation and Representation. Sage Publications, London, pp. 45-66.

Koopman, Sara., 2011. Alter-geopolitics: other securities are happening. Geoforum 42 (3), 274-284.

Laketa, Suncana, 2013. Affect and Emotion in the Formation of Geopolitical Subjects. Paper presented at the AAG 2013, Los Angeles.

Mainwaring, Scott, Scully, Timothy, 1995. Introduction: party systems in Latin America. In: Mainwaring, Scott, Scully, Timothy (Eds.), Building Democratic Institutions. Party Systems in Latin America, Stanfort, pp. 1-36.

Marcus, George E., 2002. The Sentimental Citizen: Emotion in Democratic Politics. Pennsylvania State University Press, University Park, PA.

Marcus, George E., Mackuen, Michael B., 1993. Anxiety, enthusiasm, and the vote: the emotional underpinnings of learning and involvement during presidential campaigns. The American Political Science Review 87 (3), 672-685.

Marcus, George E., MacKuen, Michael, Wolak, Jennifer, Keele, Luke, 2006. The measure and mismeasure of emotion. In: Redlawsk (Ed.), Feeling Politics: Emotion in Political Information Processing. Palgrave Macmillan, New York, pp. 31-46.

Marcus, George E., Neumann, Russell W., MacKuen, Michael, 2000. Affective Intelligence and Political Judgment. University of Chicago Press, Chicago.

Mitchell, William P., 2006. Voices from the Global Margin. Confronting Poverty and Inventing New Lines in the Andes. University of Texas Press, Austin.

Müller, Martin, 2007. What's in a word? Problematising translation between languages. Area 39 (2), 206-213.

Müller, Martin, 2009. Making Great Power Identities in Russia: An Ethnographic Discourse Analysis of Education at a Russian Elite University. LIT, Zürich.

Nelson, Lise, 1999. Bodies (and spaces) do matter: the limits of performativity. Gender, Place \& Culture: A Journal of Feminist Geography 6 (4), 331-353.

Nelson, Lise K., 2006. Geographies of state power, protest, and women's political identity formation in Michoacán, Mexico. Annals of the Association of American Geographers 96 (2), 366-389.

Pain, Rachel, 2009. Globalized fear? Towards an emotional geopolitics. Progress in Human Geography 33 (4), 466-486.

Pain, Rachel, 2010. The new geopolitics of fear. Geography Compass 4, 226-240.

Pain, Rachel, Panelli, Ruth, Kindon, Sara, Little, Jo, 2010. Moments in everyday/ distant geopolitics: young people's fears and hopes. Geoforum 41 (6), 972982.

Pile, Steve, 2010. Emotions and affect in recent human geography. Transactions of Institute of British Geographers 35 (1), 5-20.

Platán, Julio, 2005. La crisis del sistema político ecuatoriano y la caída de Gutiérrez. Íconos. Revista de Ciencias Sociales 9 (23), 45-52.

Pratt, Geraldine, 2004. Working Feminism. Edinburg University Press, Edinburgh.

Radcliffe, Sarah, 2008. Women's movement in twentieth-century Ecuador. In: De la Torre, Carlos, Striffler, Steve (Eds.), The Ecuador Reader: History, Culture, Politics. Duke University Press, Durham, pp. 284-296.

Reuber, Paul, Wolkersdorfer, Günter, 2002. Clash of Civilizations aus Sicht der kritischen Geopolitik. Geographische Rundschau 54 (7/8), 24-29.

Sánchez-Parga, José, 2007. El movimiento indígena Ecuatoriano. La larga ruta de la comunidad al partido, CAAP, Quito.

Schurr, Carolin, 2012. Visual ethnography for performative geographies: how women politicians perform identities on Ecuadorian political stages. Geographica Helvetica 67 (4), 195-202.

Schurr, Carolin, in press. Performativity and antagonism as keystones for a political geography of change. In: Glass, Michael, Rose-Redwood, Reuben (Eds.), Performativity, Politics and Social Space. Routledge, New York. 
Secor, Anna, 2004. Feminizing electoral geography. In: Staeheli, Lynn, Kofman, Eleonore, Peake, Linda (Eds.), Mapping Women, Making Politics. Feminist Perspectives on Political Geography. Routledge, New York, pp. 261-272.

Sharp, Joanne, 2011. A subaltern critical geopolitics of the war on terror: postcolonial security in Tanzania. Geoforum 42 (3), 297-305.

Simpson, Paul, 2011. 'So, as you can see...': Some reflections on the utility of video methodologies in the study of embodied practices. Area 43 (3), 343-352.

Smith, Sara., 2011. 'She says herself, "I have no future"': love, fate and territory in Leh District, India. Gender, Place \& Culture 18 (4), 455-476.

Smith, Sara, 2012. Intimate geopolitics: religion, marriage, and reproductive bodies in Leh, Ladakh. Annals of the Association of American Geographers.

Sosa-Buchholz, 2010. Changing images of male and female in Ecuador: José María Velasco Ibarra and Abdalá Bucaram. In: Kampwirth, Karen (Ed.), Gender and populism in Latin America: Passionate politics. The Pennsylvania State University Press, Pennsylvania, pp. 47-66.

Staeheli, Lynn, 1996. Publicity, privacy, and women's political action. Environment and Planning D: Society and Space 14 (5), 601-619.

Staeheli, Lynn, 2004. Mobilizing women, mobilizing gender: is it mobilizing difference? Gender, Place \& Culture: A Journal of Feminist Geography 11 (3), 347-372.

Staeheli, Lynn, Kofman, Eleonore, Peake, Linda, 2004. Mapping Women, Making Politics. Feminist Perspective on Political Geography. Routledge, New York.

Staeheli, Lynn., Mitchell, Don., 2004. Spaces of public and private: locating politics. In: Barnett, Clive, Low, Murray (Eds.), Spaces of Democracy: Geographical Perspectives on Citizenship, Participation and Representation. Sage Publications, London, pp. 147-160.
Thien, Deborah, 2005. After or beyond feeling? A consideration of affect and emotion in geography. Area 37 (4), 450-454.

Tolia-Kelly, Divya, 2006. Affect - an ethnocentric encounter? Exploring the 'universalist' imperative of emotional/affectual geographies. Area 38 (2), 213 217.

Tuaza, Luis Alberto, 2009. Cansancio Organizativo. In: Martínez, Carmen (Ed.) Repensando los movimientos indígenas. FLACSO, Quito, pp. 123-146.

Van Cott, Donna Lee, 2008. Radical Democracy in the Andes. Cambridge University Press, Cambridge.

Van Vleet, Krista, 2002. The intimacies of power: rethinking violence and affinity in the Bolivian Andes. American Ethnologist 29 (3), 567-601.

Van Zoonen, Liesbet, 2005. Entertaining the citizen: when politics and popular culture converge. Rowman \& Littlefield Publishers, Oxford.

Vega Ugalde, Silvia, 2005. La cuota electoral en Ecuador: Nadando a contracorriente en un horizonte esperanzador. In: León, Magdalena (Ed.), Nadando contra la corriente. Mujeres y cuotas políticas en los páises Andinos. UNIFEM, UNFPA FLACSO Quito, pp. 169-206.

Walsh, Catherine, García, Juan, 2002. El pensar del emergente movimiento afroecuatoriano. Reflexiones (des)de un proceso. In: Mato, Daniel (Ed.) Estudios y Otras Prácticas Intelectuales Latinoamericanas en Cultura y Poder. Consejo Latinoamericano de Ciencias Sociales (CLACSO) y CEAP, FACES Universidad Central de Venezuela, Caracas, pp. 317-326.

Warf, Barney, Leib, Jonathan, 2011. Revitalizing Electoral Geography. Ashgate Publishing Limited, Farnham.

Wetherell, Margaret, 2012. Affect and Emotions. A New Social Science Understanding. Sage, London. 